\title{
The Effects of Functional Groups and Missing Linkers on the Adsorption Capacity of Aromatic Hydrocarbons in UiO-66 Thin Films
}

\author{
Jennifer Shankwitz ${ }^{1}$, Daniel Speed ${ }^{1}$, Dillon Sinanan ${ }^{2}$ and Greg Szulczewski ${ }^{1, *}$ \\ 1 Department of Chemistry and Biochemistry, The University of Alabama, Tuscaloosa, AL 35487, USA; \\ jeshankwitz@crimson.ua.edu (J.S.); dspeed@crimson.ua.edu (D.S.) \\ 2 Department of Biological and Chemical Engineering, The University of Alabama, Tuscaloosa, AL 35487, USA; \\ djsinanan@crimson.ua.edu \\ * Correspondence: gj@@ua.edu; Tel.: +1-205-348-8428
}

Citation: Shankwitz, J.; Speed, D.; Sinanan, D.; Szulczewski, G. The Effects of Functional Groups and Missing Linkers on the Adsorption Capacity of Aromatic Hydrocarbons in UiO-66 Thin Films. Inorganics 2021, 9,1. https://doi.org/10.3390/ inorganics 9010001

Received: 26 November 2020 Accepted: 21 December 2020 Published: 26 December 2020

Publisher's Note: MDPI stays neutral with regard to jurisdictional clai$\mathrm{ms}$ in published maps and institutional affiliations.

Copyright: (C) 2020 by the authors. Licensee MDPI, Basel, Switzerland. This article is an open access article distributed under the terms and conditions of the Creative Commons Attribution (CC BY) license (https:// creativecommons.org/licenses/by/ $4.0 /)$.

\begin{abstract}
The adsorption of benzene, toluene, ethylbenzene, and xylene isomers, also known as BTEX, from the gas phase into porous thin films of the metal-organic framework UiO-66-X, where $\mathrm{X}=\mathrm{H}, \mathrm{NH}_{2}$, and $\mathrm{NO}_{2}$, was measured to quantify adsorption capacity. The thin films were grown by a vapor-conversion method onto Au-coated quartz microbalance crystals. The MOF thin films were characterized by IR and Raman spectroscopy, X-ray diffraction, X-ray photoelectron spectroscopy and scanning electron microscopy. The thin films were activated by heating under high vacuum and exposed to each gas to calculate the Henry's constant. The results demonstrate that the functional groups in the organic linker and missing-linkers both play important roles in the adsorption capacity. Several trends can be observed in the data. First, all the compounds in the BTEX family have lower Henry's constants in the UiO-66- $\mathrm{H}$ films compared to the $\mathrm{UiO}-66-\mathrm{NH}_{2}$ and $\mathrm{UiO}-66-\mathrm{NO}_{2}$ films, which can largely be attributed to the absence of a functional group on the linker. Second, at $25{ }^{\circ} \mathrm{C}$, the Henry's constants for all the BTEX compounds in UiO-66- $\mathrm{NO}_{2}$ films are larger than $\mathrm{UiO}-66-\mathrm{NH}_{2}$ films. Third, the role of missing linkers is addressed by comparing the measured adsorption capacity to ideal pore filling. The results show that the UiO-66-H films are the most defect-free and the $\mathrm{UiO}-66-\mathrm{NO}_{2}$ films have the most missing linker defects.
\end{abstract}

Keywords: BTEX adsorption; Henry's constant; metal-organic framework; thin films

\section{Introduction}

Metal-organic frameworks, or MOFs, have been widely studied over the past 20 years for possible applications in gas storage, separation, and sensors [1]. The modular nature of the synthesis has produced more than 50,000 structures, since a wide range of inorganic cations ("nodes") and organic ligands can be combined together [2]. The appropriate choice of the chemical building blocks affords a porous three-dimensional solid that exhibits extremely high surface area. However, the pores are often filled by the solvent after the synthesis and must be removed for the applications mentioned above. In addition, the mechanical stability is often limited after the solvent is removed from the porous solid. In 2008 a significant advance in MOF synthesis was reported by Lillerud and coworkers at the University of Oslo [3]. Cavka et al. reported the first synthesis of UiO-66-H using 1,4-benzenedicarboxylic acid as the organic linker and $\mathrm{Zr}$ clusters as the inorganic "nodes" [3]. The material is stable over a large $\mathrm{pH}$ range in solution and showed excellent thermal stability [4-6]. The ideal structure of a UiO-66 unit-cell consists of a zirconium-oxo cluster, $\mathrm{Zr}_{6} \mathrm{O}_{4}(\mathrm{OH})_{4}$, to form a node and six terephthalic acid linkers. In the ideal UiO-66 framework, each $\mathrm{Zr}$ ion takes the vertex in an octahedron with the $\mu_{3}-\mathrm{O}$ (triply bridging oxygen) and $\mu_{3}-\mathrm{OH}$ groups forming the eight faces $[7,8]$. The external coordination spheres of the zirconium ions are formed by carboxylate donors forming the twelve edges of the 
octahedron. In this way, the overall metal-organic framework forms as twelve clusters connected by terephthalic acid linkers to each other into a face-centered cubic array (fcu). As the nodes occupy corner and face sites of the fcu-type unit cell, the linkers will divide the cell into two types of pores, which are common in fcu-type frameworks. A single large central octahedral pore $(\sim 11 \AA)$ in the center of the unit cell is formed by the space between the six facial nodes. Smaller tetrahedral pores $(\sim 8 \AA)$ are then formed around the central pore by the linkers between three facial and one corner node, one for each corner of the cube. There are smaller triangular windows $(\sim 6 \AA)$ that connect the two pores. The effective size of the triangular window is temperature dependent because the linker can rotate [9]. Otherwise, molecules with kinetic diameters larger than the window would not be able to pass through the framework.

The fundamental adsorption, desorption and diffusion processes of hydrocarbons into MOFs has been studied because of their industrial importance [10-20]. In particular, the separation of the BTEX family of compounds is very challenging due to the similar physical properties. Industrially the separation is accomplished with a simulated moving bed using zeolites. An interesting observation was discovered by Barcia et al. when they performed breakthrough measurements with ethylbenzene and xylene isomers on UiO$66-\mathrm{H}$ pellets [21]. At $398 \mathrm{~K}$ and $423 \mathrm{~K}, o$-xylene was retained longer than $p$-xylene from a mixture of vapors containing equal concentration. This result revealed a "reverse shape selectivity" phenomena, which states that the more bulky molecule is retained in favor the least bulky molecule. After this initial finding, others observed the reverse-shape selectivity phenomena for xylene isomers in gas and liquid chromatography experiments. For example, Chang and Yan used $\mathrm{UiO}-66-\mathrm{H}$ as a stationary phase in capillary columns to separate a mixture xylene isomers and ethylbenzene [22]. They found that $p$-xylene eluted first, followed by $m$-xylene, ethylbenzene, and $o$-xylene, and calculated the adsorption enthalpy and entropy from the chromatograms. Subsequently, Duerinck et al. used inverse pulse gas chromatography to calculate the Henrys constants for BTEX compounds on a packed gas chromatography column of $\mathrm{UiO}-66-\mathrm{X}$ where $\mathrm{X}$ was $-\mathrm{H},-\mathrm{NO}_{2}$, and $-\mathrm{CH}_{3}$ groups [14]. In general, they found that decreasing the pore diameter had the largest influence on adsorption properties, rather than the specific nature of the functional group.

In addition to the experimental work, some theoretical studies have been done to better understand the reverse shape selectivity. The first attempt to theoretically study the adsorption of xylene isomers in UiO-66- $\mathrm{H}$ was performed by Granato et al. using grand-canonical Monte Carlo simulations [23]. They used four different force fields (all models assumed a rigid UiO-66-H structure) to predict isotherms at $423 \mathrm{~K}$ for ethylbenzene and the xylene isomer. In general, the simulations confirmed the experimental ortho isomer selectivity. Subsequently, molecular dynamics simulations by Lennox and Düren were aimed at better understanding the diffusion mechanism of xylene isomers in $\mathrm{UiO}-66-\mathrm{H}$ [9]. They found that rotation of the benzene dicarboxylate linker was crucial to allow passage of xylene isomers from pore to pore.

In this work, static vapor-phase adsorption of BTEX compounds into UiO-66-X thin films was studied to better understand the effect of functional groups on the adsorption of aromatic compounds. Our experimental approach is different than the previous breakthrough measurements and chromatographic studies in two ways. First, we measure the adsorption of a single compound to the MOF and second, there is no competitive adsorption from a non-adsorbing solvent. In addition, this is the first time UiO-66- $\mathrm{NH}_{2}$ has been evaluated as a sorbent for BTEX. Lastly, by performing measurements near room temperature we are able to reach saturation adsorption capacity, which reveals insight about the role of missing linker defects.

\section{Results and Discussion}

X-ray diffraction was used to assess the crystallinity of the UiO-66 thin films. Figure 1 shows the low angle Bragg peaks for the thin films. The most intense peak near $7.5^{\circ}$ corresponds to the (111) plane. A weaker reflection near $8.5^{\circ}$ is due to the (200) plane. 
In the UiO-66-H film, the (111) peak is the most intense and narrow peak, which indicates better crystallinity. In contrast, in the $\mathrm{UiO}-66-\mathrm{NO}_{2}$ film the (111) peak intensity is weaker and broader, which indicates less crystallinity. Previous work has shown the ratio of the intensity of the (111)/(200) peaks is a measure of missing linker defects [24]. The higher the intensity of the ratio of the (111)/ (200) peaks, the fewer missing linkers. Consequently, the data in Figure 1 suggest that the UiO-66- $\mathrm{H}$ films have the fewest missing linkers and the UiO-66- $\mathrm{NO}_{2}$ films have more missing linkers. Scanning electron microscopy was used to investigate the morphology and thickness of the films.

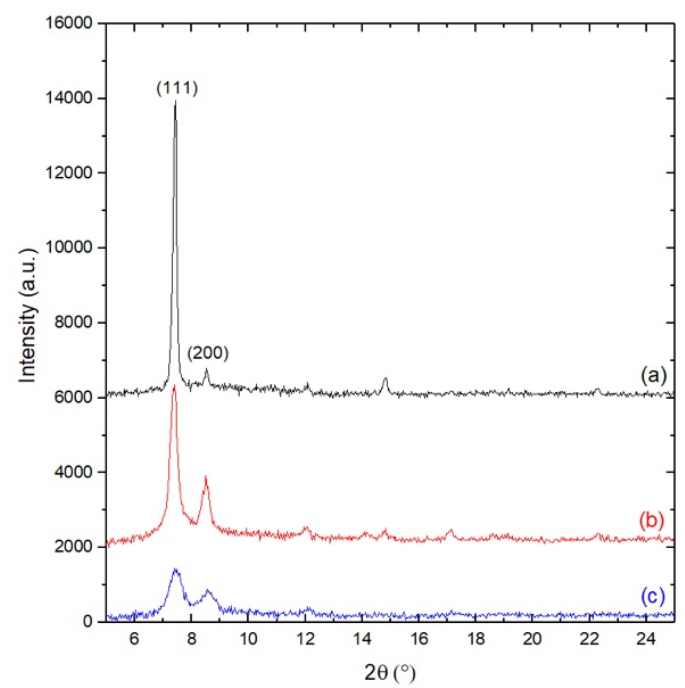

Figure 1. X-ray diffraction patterns of (a) $\mathrm{UiO}-66-\mathrm{H},(\mathbf{b}) \mathrm{UiO}-66-\mathrm{NH}_{2}$ and (c) $\mathrm{UiO}-66-\mathrm{NO}_{2}$ films.

Figure 2 shows SEM images of the top view of the UiO-66-X films. In general, each film is continuous with evidence of grain boundaries. There are some regions (not shown) where microscopic cracks are observed, which are attributed to stress while drying. Cross-section SEM images reveal the films are about 1-2 $\mu \mathrm{m}$ thick.

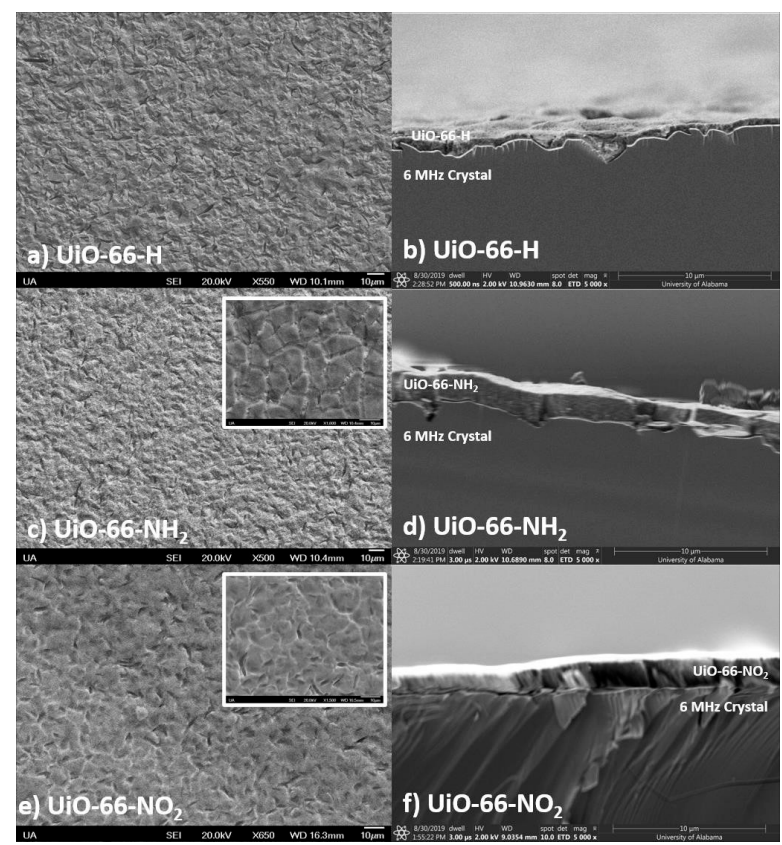

Figure 2. SEM images of UiO-66 films on QCM substrates. (a) Plane-view and (b) cross-sectional view of UiO-66-H. (c) Plane-view and (d) cross-sectional view of UiO-66-NH2 . (e) Plane-view and (f) cross-sectional view of $\mathrm{UiO}-66-\mathrm{NO}_{2}$. 
Figure 3 shows IR spectra in the fingerprint region of the synthesized $\mathrm{UiO}-66-\mathrm{H}$, $\mathrm{UiO}-66-\mathrm{NH}_{2}$, and UiO-66- $\mathrm{NO}_{2}$ films. The spectra are consistent with reports in literature for bulk powders $[4,19]$. There is a small peak around $1705-1655 \mathrm{~cm}^{-1}$ that can be assigned to the carbonyl group of residual DMF solvent in the pores (which is removed upon activation before the adsorption studies). In all three RAIRS spectra, there are a set of strong peaks between 1580 and $1395 \mathrm{~cm}^{-1}$ due to the symmetric and asymmetric carboxylate modes. There is also a strong $\mathrm{C}-\mathrm{H}$ bending mode near $770 \mathrm{~cm}^{-1}$ in all three films. There are several peaks unique to the amino and nitro functional groups. For example, in the $\mathrm{UiO}-66-\mathrm{NH}_{2}$ spectrum, the peaks at $1627 \mathrm{~cm}^{-1}$ and $1260 \mathrm{~cm}^{-1}$ are associated with the $-\mathrm{NH}_{2}$ bending mode and $\mathrm{C}-\mathrm{N}$ stretching of the amino group. In the case of the $\mathrm{UiO}-66-\mathrm{NO}_{2}$ spectrum, the peaks at $1540 \mathrm{~cm}^{-1}$ and $1346 \mathrm{~cm}^{-1}$ can be assigned to the asymmetric and symmetric stretching modes of the $\mathrm{NO}_{2}$ group.

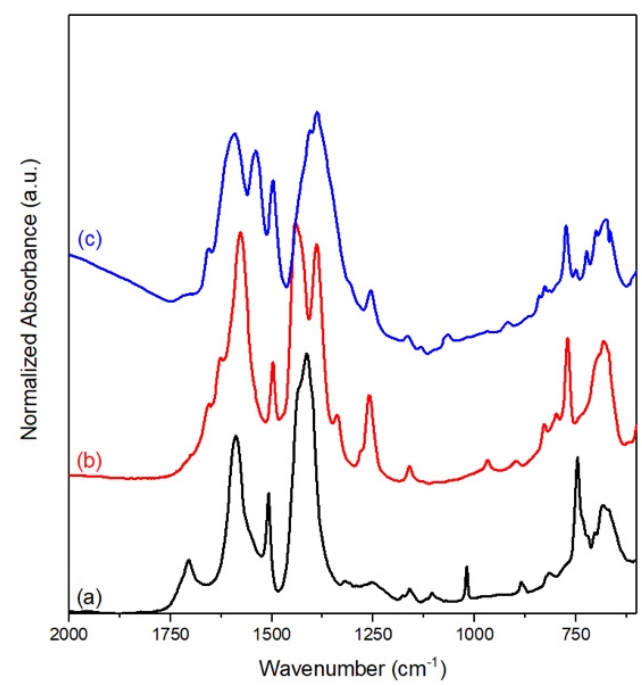

Figure 3. RAIRS of (a) UiO-66-H, (b) UiO-66- $\mathrm{NH}_{2}$ and (c) $\mathrm{UiO}-66-\mathrm{NO}_{2}$ films.

Figure 4 shows the Raman spectra from 650 to $1800 \mathrm{~cm}^{-1}$. In the spectrum for UiO-66$\mathrm{H}$, there are several strong peaks: (i) the peak at $1615 \mathrm{~cm}^{-1}$ can be assigned to the carboncarbon bond stretching mode of the aromatic ring of the linker, (ii) at peaks at $1450 \mathrm{~cm}^{-1}$ and $1430 \mathrm{~cm}^{-1}$ are two modes associated with the in-phase carboxylate stretching normal mode, (iii) the peak at $1145 \mathrm{~cm}^{-1}$ can be assigned to the breathing mode of the terephthalate ring and (iv) and a peak at $860 \mathrm{~cm}^{-1}$ due to a $\mathrm{C}-\mathrm{H}$ in-plane bending mode of the linker. In the UiO-66- $\mathrm{NO}_{2}$ Raman spectrum, there is an additional peak at $1351 \mathrm{~cm}^{-1}$ assigned to the symmetric stretching mode of the $-\mathrm{NO}_{2}$ group, and, in the $\mathrm{UiO}-66-\mathrm{NH}_{2}$ film, there is a new peak at $1265 \mathrm{~cm}^{-1}$ that can be assigned to the $-\mathrm{NH}_{2}$ bending mode.

Figure 5 shows survey $\mathrm{X}$-ray photoelectron spectra. The main peaks for the MOF nodes are the $\mathrm{O}(1 \mathrm{~s}), \mathrm{Zr}(3 \mathrm{~d})$ and $\mathrm{Zr}(3 \mathrm{p})$ peaks as seen near $520 \mathrm{eV}, 183 \mathrm{eV}$ and $330 \mathrm{eV}$, respectively. The main peak for the linker is the $\mathrm{C}(1 \mathrm{~s})$ at $285 \mathrm{eV}$. The $\mathrm{N}(1 \mathrm{~s})$ binding energy for the $\mathrm{NH}_{2}$ and $\mathrm{NO}_{2}$ groups are observed at 404 and $400 \mathrm{eV}$, respectively. There is a small $\mathrm{Au}(4 \mathrm{f})$ peak seen in the UiO-66- $\mathrm{NO}_{2}$ spectrum, which is from the substrate. The absence of $\mathrm{Cl}$ suggests there is no unreacted starting material.

Figure 6 shows a representative set of QCM data on a UiO-66- $\mathrm{NH}_{2}$ film. Similar data sets for the UiO-66- $\mathrm{H}$ and $\mathrm{UiO}-66-\mathrm{NO}_{2}$ films are shown in the Supporting Information. In each experiment, the crystal frequency was recorded at each temperature until it stabilized. Multiple runs were measured after baking the chamber. The results of the multiple runs were averaged and used to calculate the Henry's constant at each temperature (Table S1 in Supplementary Materials). There are two global trends worth noting. First, the Henry's constants on the UiO-66-H are an order of magnitude smaller than the other two MOF films. Second, the Henry's constants for the UiO-66- $\mathrm{NO}_{2}$ are greater than $\mathrm{UiO}-66-\mathrm{NH}_{2}$. 


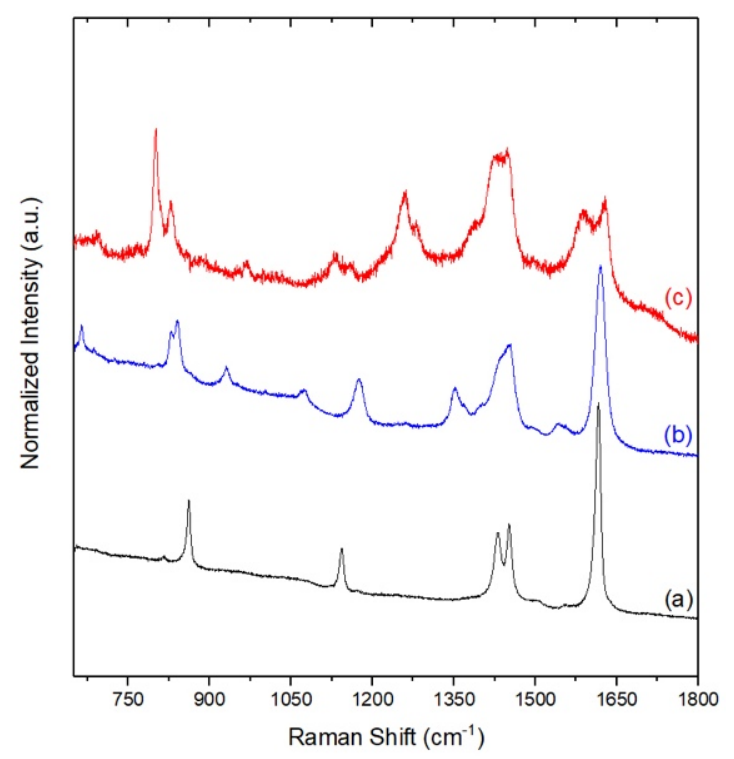

Figure 4. Raman spectra of (a) UiO-66-H, (b) UiO-66- $\mathrm{NO}_{2}$ and (c) $\mathrm{UiO}-66-\mathrm{NH}_{2}$ films.
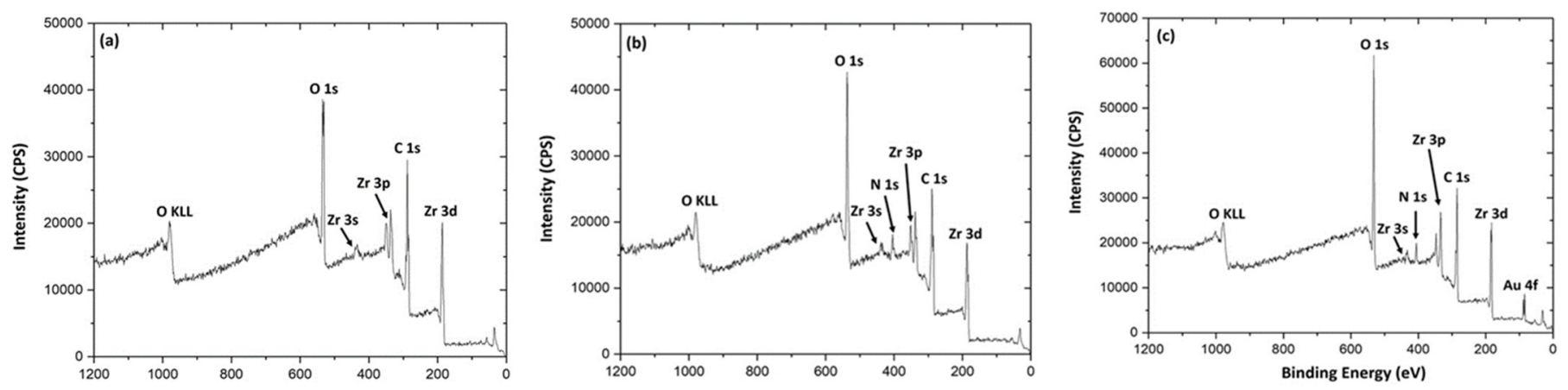

Figure 5. X-ray photoelectron spectra of (a) $\mathrm{UiO}-66-\mathrm{H},(\mathbf{b}) \mathrm{UiO}-66-\mathrm{NH}_{2}$ and (c) $\mathrm{UiO}-66-\mathrm{NO}_{2}$ films.

Our results indicate that larger substituents on the organic linker decrease the pore size and increase the interaction between the molecules and MOF framework. Previous nitrogen adsorption isotherms on $\mathrm{UiO}-66-\mathrm{X}$ have shown a direct correlation between the functional group and the pore volume and surface area [4]. For example, in UiO-66-H the surface area has been measured to be near $1300 \mathrm{~m}^{2} / \mathrm{g}$. In UiO-66- $-\mathrm{NH}_{2}$, the surface area decreases to $1250 \mathrm{~m}^{2} / \mathrm{g}$. When the amine is replaced by a nitro group in UiO-66- $\mathrm{NO}_{2}$, the surface area decreases to $856 \mathrm{~m}^{2} / \mathrm{g}$. The porosity of the framework is sensitive to the synthesis conditions. In fact, the porosity can be tuned by the addition of monocarboxylic acids that act as modulators of the crystallization process [25-27]. The monocarboxylic acids compete with binding to the nodes, which slows the crystallization kinetics and can increase the crystallite size. In addition, the monocarboxylic acid promotes the formation of missing linker defects. It is well-established that using a stronger monocarboxylic acid in the synthesis increases the surface area [25]. The increase in surface area can be attributed to either missing linkers or missing nodes. It is very challenging to provide direct evidence for the missing linker defects. Initial work using thermal gravimetric analysis inferred the missing linkers based on stoichiometry arguments. 

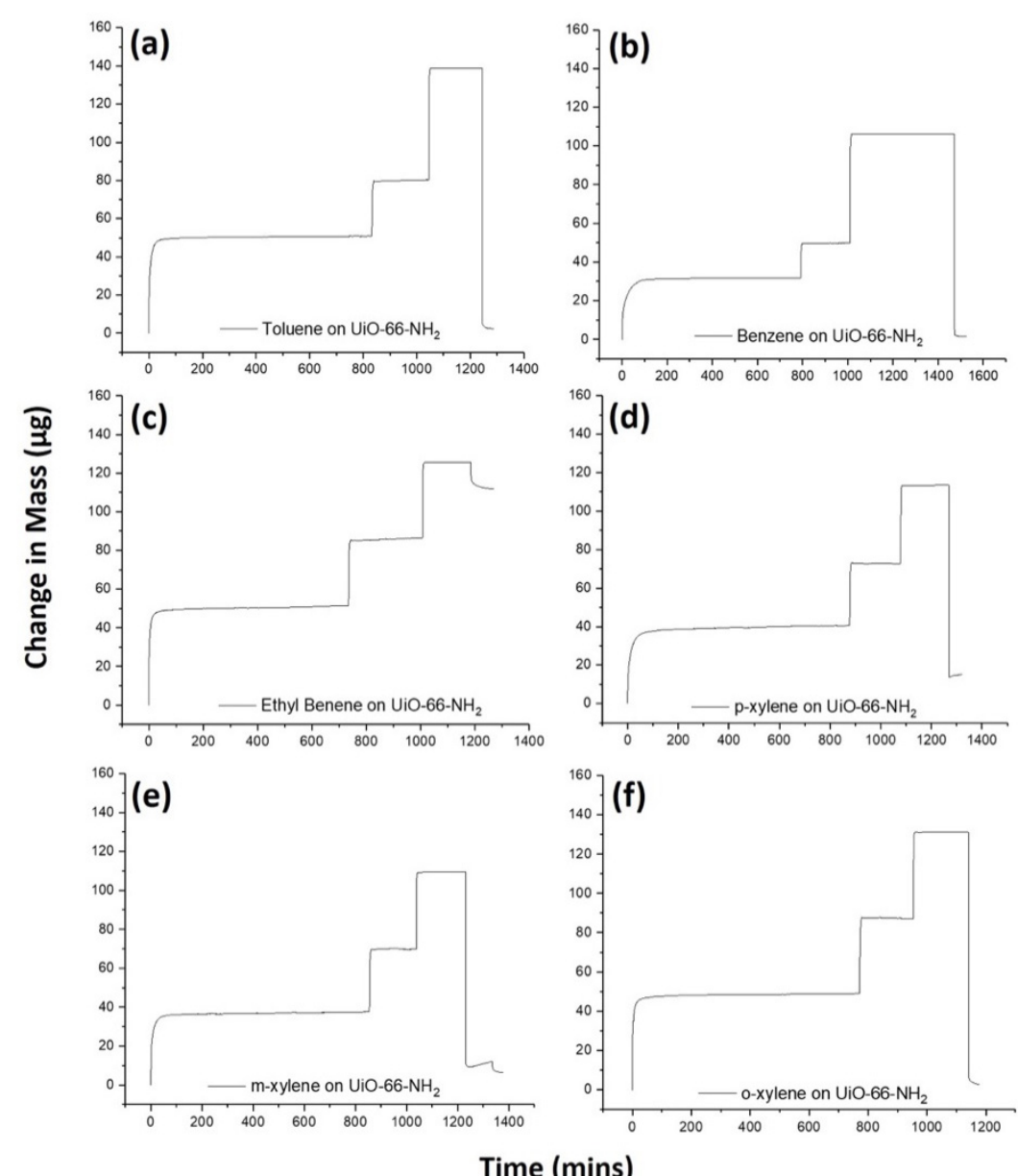

Time (mins)

Figure 6. Representative QCM data for adsorption experiments of (a) benzene, (b) toluene, (c) ethylbenzene, (d) $p$-xylene, (e) $m$-xylene, and (f) $o$-xylene on a UiO-66- $\mathrm{NH}_{2}$ film.

In 2013, Wu et al. used high-resolution powder neutron diffraction to provide the first direct structural evidence for missing linkers in the UiO-66 framework [28]. Ideally, a perfect UiO-66-H framework should have pore volume and surface area of $0.426 \mathrm{~cm}^{3} / \mathrm{g}$ and $954 \mathrm{~m}^{2} / \mathrm{g}$, respectively. If one of twelve linkers are removed, then the pore volume and surface area increase to $0.502 \mathrm{~cm}^{3} / \mathrm{g}$ and $1433 \mathrm{~m}^{2} / \mathrm{g}$, respectively. Several other groups have established the importance of missing linkers in gas adsorption studies in UiO-66 [24-34]. We have calculated the theoretical adsorption capacity (as weight percent) for each MOF assuming one BTEX molecule per pore with no missing linkers. In the ideal UiO-66-X unit cell there are four octahedral pores and eight tetrahedral pores. The Henry's constants can be converted to a weight percent to compare with the theoretical adsorption capacity assuming no defects. From the experimental measurements at $30{ }^{\circ} \mathrm{C}$ we find that, on average, there is about one BTEX molecule per unit cell for the UiO-66-H MOF. In the UiO-66- $\mathrm{NH}_{2} \mathrm{MOF}$, there are about 4-6 BTEX molecules per unit cell, and, within the UiO-66- $\mathrm{NO}_{2}$ MOFs, there are about 9-11 BTEX molecules per unit cell.

Table 1 shows the measured adsorption capacities in UiO-66- $\mathrm{NH}_{2}$ and $\mathrm{UiO}-66-\mathrm{NO}_{2}$ films exceed the theoretical adsorption capacity, which suggests that missing linkers are present. The adsorption capacity is calculated for each MOF assuming a defect free and missing-linker structure(s). In the case of the defect free unit cell, we divide the mass of 12 sorbent molecules by the mass of the perfect unit cell. In the case of one missing linker, we divide the mass of 13 sorbent molecules by the mass of the unit cell less one linker, etc. In the case of two missing linkers, we divide the mass of 14 sorbent molecules by the mass of the unit cell less one linker, etc. It can be seen the adsorption capacity for UiO-66- $\mathrm{NH}_{2}$ and $\mathrm{UiO}-66-\mathrm{NO}_{2}$ is consistent with 1-2 and 3-4 missing linkers, respectively. 
Table 1. Measured and calculated adsorption capacity (weight \%) for $\mathrm{UiO}-66-\mathrm{NH}_{2}$ and $\mathrm{UiO}-66-\mathrm{NO}_{2}$.

\begin{tabular}{|c|c|c|c|c|c|c|}
\hline Name & Defect Free & $\begin{array}{l}1 \text { Missing } \\
\text { Linker }\end{array}$ & $\begin{array}{l}2 \text { Missing } \\
\text { Linker }\end{array}$ & $\begin{array}{l}3 \text { Missing } \\
\text { Linker }\end{array}$ & $\begin{array}{l}4 \text { Missing } \\
\text { Linker }\end{array}$ & $\begin{array}{c}\text { Adsorption } \\
\text { Capacity at } 20^{\circ} \mathrm{C}\end{array}$ \\
\hline \multicolumn{7}{|l|}{$\mathrm{UiO}-66-\mathrm{NH}_{2}$} \\
\hline Benzene & $13.50 \%$ & $15.00 \%$ & $16.60 \%$ & $18.20 \%$ & $20.00 \%$ & $18.10 \%$ \\
\hline Toluene & $15.90 \%$ & $17.70 \%$ & $19.60 \%$ & $21.50 \%$ & $23.60 \%$ & $23.20 \%$ \\
\hline Ethyl benzene & $18.40 \%$ & $20.40 \%$ & $22.60 \%$ & $24.80 \%$ & $27.20 \%$ & $21.10 \%$ \\
\hline$p$-xylene & $18.40 \%$ & $20.40 \%$ & $22.60 \%$ & $24.80 \%$ & $27.20 \%$ & $19.20 \%$ \\
\hline$m$-xylene & $18.40 \%$ & $20.40 \%$ & $22.60 \%$ & $24.80 \%$ & $27.20 \%$ & $18.10 \%$ \\
\hline$o$-xylene & $18.40 \%$ & $20.40 \%$ & $22.60 \%$ & $24.80 \%$ & $27.20 \%$ & $22.00 \%$ \\
\hline \multicolumn{7}{|l|}{$\mathrm{UiO}-66-\mathrm{NO}_{2}$} \\
\hline Benzene & $12.20 \%$ & $13.60 \%$ & $15.10 \%$ & $16.60 \%$ & $18.30 \%$ & $21.60 \%$ \\
\hline Toluene & $14.40 \%$ & $16.10 \%$ & $17.80 \%$ & $19.60 \%$ & $21.60 \%$ & $21.80 \%$ \\
\hline Ethyl benzene & $16.60 \%$ & $18.50 \%$ & $20.50 \%$ & $22.60 \%$ & $24.80 \%$ & $23.60 \%$ \\
\hline p-xylene & $16.60 \%$ & $18.50 \%$ & $20.50 \%$ & $22.60 \%$ & $24.80 \%$ & $20.80 \%$ \\
\hline m-xylene & $16.60 \%$ & $18.50 \%$ & $20.50 \%$ & $22.60 \%$ & $24.80 \%$ & $24.00 \%$ \\
\hline$o$-xylene & $16.60 \%$ & $18.50 \%$ & $20.50 \%$ & $22.60 \%$ & $24.80 \%$ & $22.30 \%$ \\
\hline
\end{tabular}

In general, the role of missing linkers in UiO-66 thin films has not been studied in detail. In fact, there are very few reports of UiO-66 films grown directly onto surfaces [35-38]. This is due, in part, to the fact that the common methods for quantifying missing linkers e.g., thermal gravimetric analysis, are not amenable to thin films. To the best of our knowledge, there are only two reports in the literature of UiO-66 films grown on QCM crystals. Virmani et al. measured the adsorption of ethanol at $25^{\circ} \mathrm{C}$ into UiO-66- $\mathrm{NH}_{2}$ films [35]. Semrau et al. measured the adsorption of methanol into $\mathrm{UiO}-66-\mathrm{H}$ at $40{ }^{\circ} \mathrm{C}$ [36]. In the latter study, the authors used X-ray photoelectron spectroscopy to measure the elemental composition of films made using different amounts of a modulator. A comparison of the ideal, defect-free stoichiometry to the measured $\mathrm{Zr}, \mathrm{C}$, and $\mathrm{O}$ atomic composition can estimate the extent of defects in the films. Semrau et al. reported that films with more defects had an increased adsorption capacity of ethanol.

The role of the functional group is much more difficult to assess experimentally because it is nearly impossible to synthesize ideal materials. Several studies have reported higher adsorption capacity in $\mathrm{UiO}-66-\mathrm{NH}_{2}$ and $\mathrm{UiO}-66-\mathrm{NO}_{2}$ than $\mathrm{UiO}-66-\mathrm{H}$ [39-45]. In most cases, the smaller pore size of $\mathrm{UiO}-66-\mathrm{NO}_{2}$ and/or UiO-66- $\mathrm{NH}_{2}$ compared to $\mathrm{UiO}-66-\mathrm{H}$ is thought to contribute to stronger guest-host interactions. Demir et al. computationally screened 36 functional groups in the UiO-66 framework to assess the relative binding energies for $\mathrm{NH}_{3}, \mathrm{H}_{2} \mathrm{O}$ and $\mathrm{CO}_{2}$. The calculations revealed that the dispersion energy at the UiO-66 pore center was similar for the $\mathrm{NH}_{2}$ and $\mathrm{NO}_{2}$ functional groups. In our study, it is most likely that pi-pi interactions between the aromatic molecules and organic linkers dominate the strength of adsorption, as seen in a recent study by Akpinar et al. [46]. Overall, we conclude that the missing linkers play a more important role in our films than the nature of the functional group.

\section{Materials and Methods}

\subsection{UiO-66-X Film Synthesis}

UiO-66- $\mathrm{H}, \mathrm{UiO}-66-\mathrm{NH}_{2}$, and $\mathrm{UiO}-66-\mathrm{NO}_{2}$ thin films were synthesized using vaporassisted conversion method previously reported in the literature [35]. All chemicals used were purchased from commercial vendor and used without further purification. A precursor solution was prepared for each respective MOF. The precursor solution for $\mathrm{UiO}-66-\mathrm{H}$ was prepared by dissolving $9.345 \mathrm{mg}(0.0289 \mathrm{mmol})$ of $\mathrm{ZrOCl}_{2} \cdot 8 \mathrm{H}_{2} \mathrm{O}(99.9 \%$, trace metal basis, Bean Town Chemical, Hudson, NY, USA) in $10 \mathrm{~mL}$ of dimethylformamide (ACS regent, $\geq 99.9 \%$, Sigma Aldrich, St. Louis, MO, USA) by sonication, followed by addition of $6.12 \mathrm{mg}(0.03684 \mathrm{mmol})$ of terephthalic acid (98+\%, Alfa Aesar, Haverhill, MA, USA) and $133 \mu \mathrm{L}$ of glacial acetic acid (JT Baker, Phillipsburg, NJ, USA). The precursor solution 
for $\mathrm{UiO}-66-\mathrm{NH}_{2}$ was prepared by dissolving $28.4 \mathrm{mg}(0.08813 \mathrm{mmol})$ of $\mathrm{ZrOCl}_{2} \cdot 8 \mathrm{H}_{2} \mathrm{O}$ (99.9\%, trace metal basis, Bean Town Chemical, Hudson, NY, USA) in $10 \mathrm{~mL}$ of dimethylformamide (ACS regent, $\geq 99.9 \%$, Sigma Aldrich) by sonication, followed by addition of $16.2 \mathrm{mg}(0.08943 \mathrm{mmol})$ of 2-aminoterephthalic acid $(99 \%$, Alfa Aesar) and $400 \mu \mathrm{L}$ of glacial acetic acid (Glacial, JT Baker). The precursor solution for $\mathrm{UiO}-66-\mathrm{NO}_{2}$ was prepared by dissolving $28 \mathrm{mg}$ (0.08689 mmol) of $\mathrm{ZrOCl}_{2} \cdot 8 \mathrm{H}_{2} \mathrm{O}(99.9 \%$, trace metal basis, Bean Town Chemical) in $10 \mathrm{~mL}$ of dimethylformamide (ACS regent, $\geq 99.9 \%$, Sigma Aldrich) by sonication, followed by addition of $18.4 \mathrm{mg}(0.08715 \mathrm{mmol})$ of 2-nitroterephthalic acid ( $\geq 99.9 \%$, Sigma Aldrich) and $400 \mu \mathrm{L}$ of glacial acetic acid (Glacial, JT Baker).

Films were grown onto two types of Au substrates. Planar $200 \mathrm{~nm} \mathrm{Au} \mathrm{films} \mathrm{were}$ grown by vapor deposition onto $C r$-primed $15 \mathrm{~mm} \times 15 \mathrm{~mm}$ silicon wafers and circular $6 \mathrm{MHz}$ Au-coated quartz microbalance crystals (Inficon part \# 750-1057-G10). The substrates were placed on a Teflon o-ring, atop a stainless-steel puck that was placed on the bottom of a $50 \mathrm{~mL}$ glass jar. For each synthesis, $50 \mu \mathrm{L}$ of the respective precursor solution was pipetted onto the $\mathrm{Au}$ substrate and a $5 \mathrm{~mL}$ aliquot of vapor source solution was then deposited at the bottom of the jar. The vapor source solution was made as a mixture of dimethylformamide (ACS regent, $\geq 99.9 \%$, Sigma Aldrich) and acetic acid (Glacial, JT Baker) mixed in a 5.25:1 $v / v$ ratio. The vapor source solution was the same for all the reactions. The glass jar was sealed with a Teflon-coated lid and placed in an oven for $3 \mathrm{~h}$ at $\sim 100^{\circ} \mathrm{C}$. After $3 \mathrm{~h}$, the sealed jar was removed from the oven and allowed to cool to room temperature.

\subsection{X-ray Diffraction}

X-ray diffraction spectra were obtained on the films using a Bruker D2 Phaser with $\mathrm{Cu} \mathrm{k} \alpha$ radiation (Bruker AXS, Karlsruhle, Germany). Spectra were collected over 5-25 with a 0.24 step size and collected for $12 \mathrm{~min}$.

\subsection{Reflection-Infrared Absorption Spectroscopy (RAIRS)}

A Bruker Vertex 70 spectrometer (Bruker Scientific, Billerica, MA, USA) was used to collect reflection-absorption infrared spectroscopy (RAIRS) data. The spectrometer was purged with nitrogen gas after 20 min and spectra were collected as an average over 64 scans with a resolution of $4 \mathrm{~cm}^{-1}$.

\subsection{Raman Spectroscopy}

Raman spectra were collected on a Horiba LabRAM HR800 (Horiba France SAS, Longjumeau, France) using a back-scattering geometry with a $10 \mathrm{X}$ microscope objective. Raman spectra for the UiO-66- $\mathrm{H}$ and $\mathrm{UiO}-66-\mathrm{NO}_{2}$ thin films were excited with $532 \mathrm{~nm}$ excitation. The scattered radiation was dispersed onto a 1800 groove $/ \mathrm{mm}$ diffraction grating. The spectra represent the average of 8 scans with a total acquisition time of $30 \mathrm{~s}$ per scan. The UiO-66- $\mathrm{NH}_{2}$ films exhibit photoluminescence with $532 \mathrm{~nm}$ excitation so $784 \mathrm{~nm}$ excitation was used instead. The scattered radiation was dispersed onto a 950 grooves $/ \mathrm{mm}$ diffraction grating. The spectra represent the average of 32 scans with a total acquisition time of 15 s per scan.

\subsection{Scanning Electron Microscopy (SEM)}

SEM images were taken on a JEOL-7000 FE Scanning Electron Microscope and a Thermo Scientific Apreo FE-SEM. Plane-view and cross-sectional SEM images were taken on films grown on the $6 \mathrm{MHz}$ quartz microbalance crystals.

\subsection{X-ray Photoelectron Spectroscopy}

X-ray photoelectron spectra (Kratos Analytical, Manchester, UK) were taken on a Kratos Axis Ultra DLD using a $45^{\circ}$ take-off-angle and $80 \mathrm{eV}$ pass energy. Charge neutralization was used and the C(1s) binding energy was set to $285 \mathrm{eV}$ in each spectrum. 


\subsection{Gas Doser}

In a glovebox (LC Technology Solutions, Salisbury, CMA, USA), the commercially purchased BTEX liquids were transferred into sealed bottles with molecular sieves ( $3 \AA$ ) for a minimum of 2 weeks. Approximately $20 \mathrm{~mL}$ of each liquid was transferred into a glass ampule fused to a glass-metal joint. The stainless-steel tube was connected to a Nupro valve with Swagelok compression fittings. After the fittings were tightened in the glovebox, the doser was removed and attached to a stainless-steel vacuum chamber. The liquid was subjected to three freeze-pump-thaw cycles to remove the nitrogen gas in the headspace of the ampule.

\subsection{Quartz Crystal Microbalance Studies}

The MOF-coated $6 \mathrm{MHz}$ QCM crystals were mounted in a high vacuum, stainless steel bakeable sensor (Inficon, Syracuse, NY, USA). The flange was bolted to a stainless-steel vacuum chamber with a conflat flange. The output of the sensor was monitored with an Inficon XTM/2 controller and the crystal frequency was recorded with a home-made Labview program. The MOF film was activated by baking the chamber at $\sim 100{ }^{\circ} \mathrm{C}$ for about $12 \mathrm{~h}$ under high vacuum. After activation, the chamber was allowed to cool to room temperature. The base pressure of the chamber was less than $1 \times 10^{-7}$ Torr. The experimental protocol involved stabilizing the crystal temperature initially at $30^{\circ} \mathrm{C}$ with an external temperature controller to within $\pm 0.1^{\circ} \mathrm{C}$. A gate valve between the stainlesssteel chamber and turbomolecular pump was closed and the valve to doser was opened. Once the crystal frequency stabilized, the temperature was decreased to $25^{\circ} \mathrm{C}$. The same procedure was repeated down to $20^{\circ} \mathrm{C}$. After the crystal frequency stabilized at $20^{\circ} \mathrm{C}$, the valve to the doser was closed. During the entire experiment, the gas pressure was monitored by a convectron gauge. At the end of data collection, the gate valve to the pump was opened and the residual gas in the chamber was pumped out before starting the bakeout for the next adsorption cycle. At least three adsorption cycles were recorded for each compound on each MOF film. The crystal frequency was converted to a mass using the Sauerbrey equation shown below in Equation (1)

$$
\Delta f=-\frac{2 \mathrm{f}_{0}^{2}}{\mathrm{~A} \sqrt{\rho_{\mathrm{q}} \mu_{\mathrm{q}}}} \Delta m
$$

where $\Delta f=$ change in frequency, $\mathrm{f}_{0}=$ resonant frequency $(6 \mathrm{MHz}), \mathrm{A}=$ area of crystal $\left(1.54 \mathrm{~cm}^{2}\right), \rho_{\mathrm{q}}=$ density of quartz $\left(2.649 \mathrm{~g} / \mathrm{cm}^{3}\right), \mu_{\mathrm{q}}=$ shear modulus of quartz $\left(3.32 \times 10^{11} \mathrm{dyn} / \mathrm{cm}^{2}\right)$, and $\Delta m=$ change in mass. Specifically, for our $6 \mathrm{MHz}$ crystals the conversion factor is: $20.05 \mathrm{ng} / \mathrm{Hz}$. The Henry's constant, shown in Equation (2), was calculated by dividing the number of moles of adsorbed compound by the product of mass of the MOF thin film (in $\mathrm{kg}$ ) and pressure of the gas (in Pa). The average values and standard deviation were calculated.

$$
\mathrm{K}_{\mathrm{H}}=\frac{\text { moles of adsorbate }}{\text { mass of MOF film } \times \text { pressure }}=\frac{\mathrm{mol}}{\mathrm{kg} \cdot \mathrm{Pa}}
$$

\section{Conclusions}

Thin films of the UiO-66-X MOF were synthesized on Au coated QCM crystal surfaces and retained the porosity observed in bulk powders. The UiO-66- $\mathrm{H}$ films have the smallest Henrys constant across the BTEX family of compounds at room temperature. This result suggests that the lack of a functional group and larger pore size of $\mathrm{UiO}-66-\mathrm{H}$ results in weaker adsorbate-adsorbent interactions and, therefore, the smallest Henry's constant. The experimental results suggest that defects strongly influence adsorption capacity. Specifically, the results suggest that the $\mathrm{UiO}-66-\mathrm{NO}_{2}$ films used in this work contain more missing linker defects than the UiO-66- $\mathrm{NH}_{2}$ films. It was estimated that the UiO-66- $\mathrm{NH}_{2}$ films have at least two missing linkers per unit cell and the $\mathrm{UiO}-66-\mathrm{NO}_{2}$ films have $3-4$ missing linkers per unit cell. In contrast, the greater number of missing linker defects in the UiO-66- $\mathrm{NO}_{2}$ 
films effectively increases the pore size, which can accommodate more molecules per unit cell and increase the Henry's constants.

Supplementary Materials: The following are available online at https://www.mdpi.com/2304-6 $740 / 9 / 1 / 1 / s 1$, Figures S1 and S2 show representative adsorption data for the UiO-66- $\mathrm{NO}_{2}$ and UiO-66-H films, respectively. Table S1 summarizes the Henry's constants measured at 30, 25, and $20^{\circ} \mathrm{C}$.

Author Contributions: Conceptualization, G.S.; methodology, G.S. and J.S.; software, D.S. (Dillon Sinanan) and D.S. (Daniel Speed); validation, J.S., D.S. (Daniel Speed) and G.S.; formal analysis, J.S.; investigation, J.S.; resources, G.S.; data curation, J.S.; writing—original draft preparation, G.S.; writing-review and editing, G.S., J.S., D.S. (Daniel Speed) and D.S. (Dillon Sinanan); visualization, J.S. and D.S. (Daniel Speed); supervision, G.S.; project administration, G.S.; funding acquisition, G.S. All authors have read and agreed to the published version of the manuscript.

Funding: This research was funded in part by the US Department of Education, grant number \#P200A150329.

Institutional Review Board Statement: Not applicable.

Informed Consent Statement: Not applicable.

Data Availability Statement: Not appliacable.

Acknowledgments: We would like to thank Paul Rupar for access to his glovebox and Michael Buettner for help collecting the X-ray photoelectron spectra.

Conflicts of Interest: The authors declare no conflict of interest.

\section{References}

1. Li, H.; Eddaoudi, M.; O'Keeffe, M.; Yaghi, O.M. Design and synthesis of an exceptionally stable and highly porous metal-organic framework. Nature 1999, 402, 276-279. [CrossRef]

2. Moghadam, P.Z.; Li, A.; Wiggin, S.B.; Tao, A.; Maloney, A.G.P.; Wood, P.A.; Ward, S.C.; Fairen-Jimenez, D. Development of a Cambridge Structural Database Subset: A Collection of Metal-Organic Frameworks for Past, Present, and Future. Chem. Mater. 2017, 29, 2618-2625. [CrossRef]

3. Cavka, J.H.; Jakobsen, S.; Olsbye, U.; Guillou, N.; Lamberti, C.; Bordiga, S.; Lillerud, K.P. A New Zirconium Inorganic Building Brick Forming Metal Organic Frameworks with Exceptional Stability. J. Am. Chem. Soc. 2008, 130, 13850-13851. [CrossRef] [PubMed]

4. Kandiah, M.; Nilsen, M.H.; Usseglio, S.; Jakobsen, S.; Olsbye, U.; Tilset, M.; Larabi, C.; Quadrelli, E.A.; Bonino, F.; Lillerud, K.P. Synthesis and Stability of Tagged UiO-66 Zr-MOFs. Chem. Mater. 2010, 22, 6632-6640. [CrossRef]

5. Shearer, G.C.; Forselv, S.; Chavan, S.; Bordiga, S.; Mathisen, K.; Bjørgen, M.; Svelle, S.; Lillerud, K.P. In Situ Infrared Spectroscopic and Gravimetric Characterisation of the Solvent Removal and Dehydroxylation of the Metal Organic Frameworks UiO-66 and UiO-67. Top. Catal. 2013, 56, 770-782. [CrossRef]

6. DeCoste, J.B.; Peterson, G.W.; Jasuja, H.; Glover, T.G.; Huang, Y.-G.; Walton, K.S. Stability and degradation mechanisms of metal-organic frameworks containing the $\mathrm{Zr}_{6} \mathrm{O}_{4}(\mathrm{OH})_{4}$ secondary building unit. J. Mater. Chem. A 2013, 1, 5642-5650. [CrossRef]

7. Valenzano, L.; Civalleri, B.; Chavan, S.; Bordiga, S.; Nilsen, M.H.; Jakobsen, S.; Lillerud, K.P.; Lamberti, C. Disclosing the Complex Structure of UiO-66 Metal Organic Framework: A Synergic Combination of Experiment and Theory. Chem. Mater. 2011, 23, 1700-1718. [CrossRef]

8. Øien, S.; Wragg, D.; Reinsch, H.; Svelle, S.; Bordiga, S.; Lamberti, C.; Lillerud, K.P. Detailed Structure Analysis of Atomic Positions and Defects in Zirconium Metal-Organic Frameworks. Cryst. Growth Des. 2014, 14, 5370-5372. [CrossRef]

9. Lennox, M.J.; Düren, T. Understanding the Kinetic and Thermodynamic Origins of Xylene Separation in UiO-66(Zr) via Molecular Simulation. J. Phys. Chem. C 2016, 120, 18651-18658. [CrossRef]

10. Finsy, V.; Verelst, H.; Alaerts, L.; De Vos, D.; Jacobs, P.A.; Baron, G.V.; Denayer, J.F.M. Pore-Filling-Dependent Selectivity Effects in the Vapor-Phase Separation of Xylene Isomers on the Metal-Organic Framework MIL-47. J. Am. Chem. Soc. 2008, 130, 7110-7118. [CrossRef]

11. Gu, Z.-Y.; Jiang, D.-Q.; Wang, H.-F.; Cui, X.-Y.; Yan, X.-P. Adsorption and Separation of Xylene Isomers and Ethylbenzene on Two Zn-Terephthalate Metal-Organic Frameworks. J. Phys. Chem. C 2010, 114, 311-316. [CrossRef]

12. Rives, S.; Jobic, H.; Kolokolov, D.I.; Gabrienko, A.A.; Stepanov, A.G.; Ke, Y.; Frick, B.; Devic, T.; Férey, G.; Maurin, G. Diffusion of Xylene Isomers in the MIL-47(V) MOF Material: A Synergic Combination of Computational and Experimental Tools. J. Phys. Chem. C 2013, 117, 6293-6302. [CrossRef]

13. Peralta, D.; Chaplais, G.; Paillaud, J.-L.; Simon-Masseron, A.; Barthelet, K.; Pirngruber, G.D. The separation of xylene isomers by ZIF-8: A demonstration of the extraordinary flexibility of the ZIF-8 framework. Microporous Mesoporous Mater. 2013, 173, 1-5. [CrossRef] 
14. Duerinck, T.; Bueno-Perez, R.; Vermoortele, F.; De Vos, D.E.; Calero, S.; Baron, G.V.; Denayer, J.F.M. Understanding Hydrocarbon Adsorption in the UiO-66 Metal-Organic Framework: Separation of (Un) saturated Linear, Branched, Cyclic Adsorbates, Including Stereoisomers. J. Phys. Chem. C 2013, 117, 12567-12578. [CrossRef]

15. Ramsahye, N.A.; Gao, J.; Jobic, H.; Llewellyn, P.L.; Yang, Q.; Wiersum, A.D.; Koza, M.M.; Guillerm, V.; Serre, C.; Zhong, C.L.; et al. Adsorption and Diffusion of Light Hydrocarbons in UiO-66(Zr): A Combination of Experimental and Modeling Tools. J. Phys. Chem. C 2014, 118, 27470-27482. [CrossRef]

16. Trens, P.; Belarbi, H.; Shepherd, C.; Gonzalez, P.; Ramsahye, N.A.; Lee, U.H.; Seo, Y.-K.; Chang, J.-S. Adsorption and separation of xylene isomers vapors onto the chromium terephthalate-based porous material MIL-101(Cr): An experimental and computational study. Microporous Mesoporous Mater. 2014, 183, 17-22. [CrossRef]

17. Gonzalez, M.I.; Kapelewski, M.T.; Bloch, E.D.; Milner, P.J.; Reed, D.A.; Hudson, M.R.; Mason, J.A.; Barin, G.; Brown, C.M.; Long, J.R. Separation of Xylene Isomers through Multiple Metal Site Interactions in Metal-Organic Frameworks. J. Am. Chem. Soc. 2018, 140, 3412-3422. [CrossRef]

18. Grissom, T.G.; Sharp, C.H.; Usov, P.M.; Troya, D.; Morris, A.J.; Morris, J.R. Benzene, Toluene, and Xylene Transport through UiO-66: Diffusion Rates, Energetics, and the Role of Hydrogen Bonding. J. Phys. Chem. C 2018, 122, 16060-16069. [CrossRef]

19. Driscoll, D.M.; Troya, D.; Usov, P.M.; Maynes, A.J.; Morris, A.J.; Morris, J.R. Characterization of Undercoordinated Zr Defect Sites in UiO-66 with Vibrational Spectroscopy of Adsorbed CO. J. Phys. Chem. C 2018, 122, 14582-14589. [CrossRef]

20. Cui, W.-G.; Hu, T.-L.; Bu, X.-H. Metal-Organic Framework Materials for the Separation and Purification of Light Hydrocarbons. Adv. Mater. 2020, 32, 1806445. [CrossRef]

21. Bárcia, P.S.; Guimarães, D.; Mendes, P.A.P.; Silva, J.A.C.; Guillerm, V.; Chevreau, H.; Serre, C.; Rodrigues, A.E. Reverse shape selectivity in the adsorption of hexane and xylene isomers in MOF UiO-66. Microporous Mesoporous Mater. 2011, 139, 67-73. [CrossRef]

22. Chang, N.; Yan, X.-P. Exploring reverse shape selectivity and molecular sieving effect of metal-organic framework UIO-66 coated capillary column for gas chromatographic separation. J. Chromatogr. A 2012, 1257, 116-124. [CrossRef] [PubMed]

23. Granato, M.A.; Martins, V.D.; Ferreira, A.F.P.; Rodrigues, A.E. Adsorption of xylene isomers in MOF UiO-66 by molecular simulation. Microporous Mesoporous Mater. 2014, 190, 165-170. [CrossRef]

24. Katz, M.J.; Brown, Z.J.; Colón, Y.J.; Siu, P.W.; Scheidt, K.A.; Snurr, R.Q.; Hupp, J.T.; Farha, O.K. A facile synthesis of UiO-66, UiO-67 and their derivatives. Chem. Commun. 2013, 49, 9449-9451. [CrossRef] [PubMed]

25. Shearer, G.C.; Chavan, S.; Bordiga, S.; Svelle, S.; Olsbye, U.; Lillerud, K.P. Defect Engineering: Tuning the Porosity and Composition of the Metal-Organic Framework UiO-66 via Modulated Synthesis. Chem. Mater. 2016, 28, 3749-3761. [CrossRef]

26. Morris, W.; Wang, S.; Cho, D.; Auyeung, E.; Li, P.; Farha, O.K.; Mirkin, C.A. Role of Modulators in Controlling the Colloidal Stability and Polydispersity of the UiO-66 metal-Organic framework. ACS Appl. Mater. Interfaces 2017, 9, 33413-33418. [CrossRef]

27. Atzori, C.; Shearer, G.C.; Maschio, L.; Civalleri, B.; Bonino, F.; Lamberti, C.; Svelle, S.; Lillerud, K.P.; Bordiga, S. Effect of Benzoic Acid as a Modulator in the Structure of UiO-66: An Experimental and Computational Study. J. Phys. Chem. C 2017, 121, 9312-9324. [CrossRef]

28. Wu, H.; Chua, Y.S.; Krungleviciute, V.; Tyagi, M.; Chen, P.; Yildirim, T.; Zhou, W. Unusual and Highly Tunable Missing-Linker Defects in Zirconium Metal-Organic Framework UiO-66 and Their Important Effects on Gas Adsorption. J. Am. Chem. Soc. 2013, 135, 10525-10532. [CrossRef]

29. Cliffe, M.J.; Wan, W.; Zou, X.; Chater, P.A.; Kleppe, A.K.; Tucker, M.G.; Wilhelm, H.; Funnell, N.P.; Coudert, F.-X.; Goodwin, A.L. Correlated defect nanoregions in a metal-organic framework. Nat. Commun. 2014, 5, 4176. [CrossRef]

30. Shearer, G.C.; Chavan, S.; Ethiraj, J.; Vitillo, J.G.; Svelle, S.; Olsbye, U.; Lamberti, C.; Bordiga, S.; Lillerud, K.P. Tuned to Perfection: Ironing Out the Defects in Metal-Organic Framework UiO-66. Chem. Mater. 2014, 26, 4068-4071. [CrossRef]

31. Vandichel, M.; Hajek, J.; Vermoortele, F.; Waroquier, M.; De Vos, D.E.; Van Speybroeck, V. Active site engineering in UiO66 type metal-organic frameworks by intentional creation of defects: A theoretical rationalization. CrystEngComm 2015, 17, 395-406. [CrossRef]

32. Liang, W.; Coghlan, C.J.; Ragon, F.; Rubio-Martinez, M.; D’Alessandro, D.M.; Babarao, R. Defect engineering of UiO-66 for CO 2 and $\mathrm{H}_{2} \mathrm{O}$ uptake-A combined experimental and simulation study. Dalton Trans. 2016, 45, 4496-4500. [CrossRef] [PubMed]

33. Idrees, K.B.; Chen, Z.; Zhang, X.; Mian, M.R.; Drout, R.J.; Islamoglu, T.; Farha, O.K. Tailoring Pore Aperture and Structural Defects in Zirconium-Based Metal-Organic Frameworks for Krypton/Xenon Separation. Chem. Mater. 2020, 32, 3776-3782. [CrossRef]

34. Winarta, J.; Shan, B.; McIntyre, S.M.; Ye, L.; Wang, C.; Liu, J.; Mu, B. A Decade of UiO-66 Research: A Historic Review of Dynamic Structure, Synthesis Mechanisms, and Characterization Techniques of an Archetypal Metal-Organic Framework. Cryst. Growth Des. 2020, 20, 1347-1362. [CrossRef]

35. Virmani, E.; Rotter, J.M.; Mähringer, A.; von Zons, T.; Godt, A.; Bein, T.; Wuttke, S.; Medina, D.D. On-Surface Synthesis of Highly Oriented Thin Metal-Organic Framework Films through Vapor-Assisted Conversion. J. Am. Chem. Soc. 2018, 140, 4812-4819. [CrossRef]

36. Semrau, A.L.; Wannapaiboon, S.; Pujari, S.P.; Vervoorts, P.; Albada, B.; Zuilhof, H.; Fischer, R.A. Highly Porous Nanocrystalline UiO-66 Thin Films via Coordination Modulation Controlled Step-by-Step Liquid-Phase Growth. Cryst. Growth Des. 2019, 19, 1738-1747. [CrossRef]

37. Miyamoto, M.; Kohmura, S.; Iwatsuka, H.; Oumi, Y.; Uemiya, S. In situ solvothermal growth of highly oriented Zr-based metal organic framework UiO-66 film with monocrystalline layer. CrystEngComm 2015, 17, 3422-3425. [CrossRef] 
38. Hashem, T.; Valdez Sanchez, E.P.; Weidler, P.; Gliemann, H.; Alkordi, M.H.; Wöll, C. Liquid-Phase Quasi-Epitaxial Growth of Highly Stable, Monolithic UiO-66- $\mathrm{NH}_{2}$ MOF thin Films on Solid Surfaces. ChemistryOpen 2020, 9, 524-527. [CrossRef]

39. Cmarik, G.E.; Kim, M.; Cohen, S.M.; Walton, K.S. Tuning the Adsorption Properties of UiO-66 via Ligand Functionalization. Langmuir 2012, 28, 15606-15613. [CrossRef]

40. Jasuja, H.; Peterson, G.W.; Decoste, J.B.; Browe, M.A.; Walton, K.S. Evaluation of MOFs for air purification and air quality control applications: Ammonia removal from air. Chem. Eng. Sci. 2015, 124, 118-124. [CrossRef]

41. DeCoste, J.B.; Browe, M.A.; Wagner, G.W.; Rossin, J.A.; Peterson, G.W. Removal of chlorine gas by an amine functionalized metal-organic framework via electrophilic aromatic substitution. Chem. Commun. 2015, 51, 12474-12477. [CrossRef] [PubMed]

42. Peterson, G.W.; DeCoste, J.B.; Fatollahi-Fard, F.; Britt, D.K. Engineering UiO-66- $\mathrm{NH}_{2}$ for Toxic Gas Removal. Ind. Eng. Chem. Res. 2014, 53, 701-707. [CrossRef]

43. Rada, Z.H.; Abid, H.R.; Sun, H.; Shang, J.; Li, J.; He, Y.; Liu, S.; Wang, S. Effects of $-\mathrm{NO}_{2}$ and $-\mathrm{NH}_{2}$ functional groups in mixed-linker Zr-based MOFs on gas adsorption of $\mathrm{CO}_{2}$ and $\mathrm{CH}_{4}$. Prog. Nat. Sci. Mater. Int. 2018, 28, 160-167. [CrossRef]

44. Vellingiri, K.; Kumar, P.; Deep, A.; Kim, K.-H. Metal-organic frameworks for the adsorption of gaseous toluene under ambient temperature and pressure. Chem. Eng. J. 2017, 307, 1116-1126. [CrossRef]

45. Demir, H.; Walton, K.S.; Sholl, D.S. Computational Screening of Functionalized UiO-66 Materials for Selective Contaminant Removal from Air. J. Phys. Chem. C 2017, 121, 20396-20406. [CrossRef]

46. Akpinar, I.; Drout, R.J.; Isamoglu, T.; Kato, S.; Lyu, J.; Farha, O.K. Exploiting $\pi-\pi$ interactions to design an efficient sorbent for atrazine removal from water. ACS Appl. Mater. Interfaces 2019, 11, 6097-6103. [CrossRef] 